\title{
受賞記念解説 一 高圧力学会賞
}

\section{複合極限下における物性測定装置開発と それを用いた特異な電子状態を持つ 物質の電子物性の研究}

High-Pressure Apparatus at Multi-Extreme Conditions and Its Application for the Research of Condensed Matters with Novel Electronic States

\section{巨海 玄道}

OOMI Gendo

\begin{abstract}
A versatile high-pressure apparatus has been constructed to measure the electronic, magnetic and thermal properties of metals, alloys and compounds at low temperature and high magnetic field. A pressure-induced crossover from heavy fermion to intermediate valence state and pressure-induced superconductivity are reported for some intermetallic compounds including $\mathrm{f}$ electrons. The effect of pressure on the giant magnetoresistance (GMR) for nanoscale magnetic materials is described. The enhancement of GMR is found at high pressure. The Compton scattering at high pressure is also reported as an interesting topic.
\end{abstract}

[Multiextreme conditions, pressure-induced crossover, superconductivity, nanoscale magnet, Compton scattering $]$

1. はじめに

自然科学の研究を行う時, 通常, 我々は自分の得 意分野をキーワードとして研究を進めていく。私の 場合, 強いて挙げれば「高圧力」と「電子物性」な どが出てくる。“強いて挙げれば”と言う意味は, その $2 つ の$ 分野で私は必ずしもエクスパートとは言 えないということである。ただ，私を取り巻いてき た（有能なエクスパートと言える）人とそれなりの 研究環境に恵まれて本人の能力の低さにも拘らず, ある程度の成果を出すことができたということが本 当の所である。私はこれまでいくつかの大学に所属 し，そこで研究室を開設して研究を続けてきたが， そのテーマは「高圧力下の電子物性研究」であった ことは一貫している。私の高圧研究の出発点は広島 大学に拈ける高圧力下の X 線回折の実験であった。 その時, 回りで静水圧を用いた高圧力下の磁性の研 究を行っている人がいたが，なんで高圧を出すのに
液体が必要なのか素朴な疑問を抱いた。当時の私の 高圧物性への理解はその程度のものであった。今思 い返すと何とも赤面の至りである。博士課程を北海 道大学ですごし, 助手時代を含めて約 13 年の間, 低温・高圧の物性実験に本格的に取り組んだ $[1]$ 。 ここで私は圧力発生技術の初歩から試料つくり, 電 気・磁気測定など幅広い高圧物性実験技術を身に付 けることとなった。

研究を進める過程で大学は 1990 年代の大学設置 基準の大綱化に始まり多くの変革があり, 私が研究 室を持つようになったのは，以下で述べるように丁 度そのころであったため，その荒波をかぶりながら 研究を継続しなければならなかった。そして，そこ でも私は高圧又は極限と言うことをキーワードにし て物事（研究及び研究体制）を進めていくことにな った。そこではいかに研究を続けるべきか，どんな 体制で研究をつづけた方がよいかなど多くの課題に 直面した。本稿では，そのような中で研究をいかに

干830-0052 福岡県久留米市上津町 2228-66 久留米工業大学工学部

Kurume Institute of Technology, 2228-66 Kamitsu-machi, Kurume, Fukuoka 830-0052

Electronic address: geomi@cc.kurume-it.ac.jp 
続けてきたか，またそれを支える体制の構築につい て私の経験を紹介し，これから活躍される多くの人 たちの何かの参考になればと思う。

\section{2. 複数極端 (複合極限) 条件（低温·高圧 ·高磁 場）下における物性測定装置の開発}

1987 年の夏の終わりに熊本大学教養部へ異動し た。当時は学生もいなく, 私の部屋があった 4 階建 ての教養部 A 棟は午後 7 時を過ぎると宿直の人を 除いては誰もいなくなり, 着任後しばらくは薄暗い 部屋で天井を見ながらボーッとして過ごした。しか し，そういう毎日ばかりでは建設的でないと思い， 予算はなかったが北大時代から暖めてきたアイデア を実現しようと考え, 高圧装置開発に着手した。講 義・学生実験を終えた午後 7 時ごろから上で述べた ような静寂な理想的な環境の下で紙と鉛筆と定規・ コンパス等を用いて装置の設計に取り掛かった。夜 も更けて州るころになると A 棟に居るのは自分だ けという日も多かった。幸いなことに, その後, 助 手や大学院生が研究室に入ってきて装置開発は飛躍 的に進むこととなった。

高圧装置の設計は目標とする温度や圧力によって, あるいは対象物質や測定する物理量によって, 異な ってくる。本装置は高圧力下で精密物性測定とその 効率化を目指して開発された。これまでの低温・高 圧装置は手軽さと言う観点からクランプ型が主であ った。本装置はこれらの装置と違って, 圧力・磁場 を広い温度範囲で自由に変化できるものであった (Fig. 1, [2,3])。ピストン・シリンダー装置を念頭 に置いたため, 試料空間の容量が大きく, 電気測定 ばかりでなく磁気測定や熱膨張測定等にも適用でき 幅広い用途を持っていた。また， 3 条件を同時に変 化させるため実験の効率やデータの質がよくなるこ とも判明した。特徵の一つに超伝導マグネットを使 用した磁場が入っているため, 例えば磁気抵抗や磁 歪の測定が容易に行えた。このため体積变化を伴う 相転移の検出や巨大磁気抵抗効果などは格好のテー マとなった。

この装置が動くまでは多くのトラブルを経験した が，当時のスタッフや院生たちの努力でやっと使え るようになった。その後, 国内の何か所かでこの装 置と類似の装置が作られた。さらに改良を加え, 九 州大学に移ってから 2 号機を作製した。本装置の構 造は単純であり, Swenson 型の装置に単に超伝導

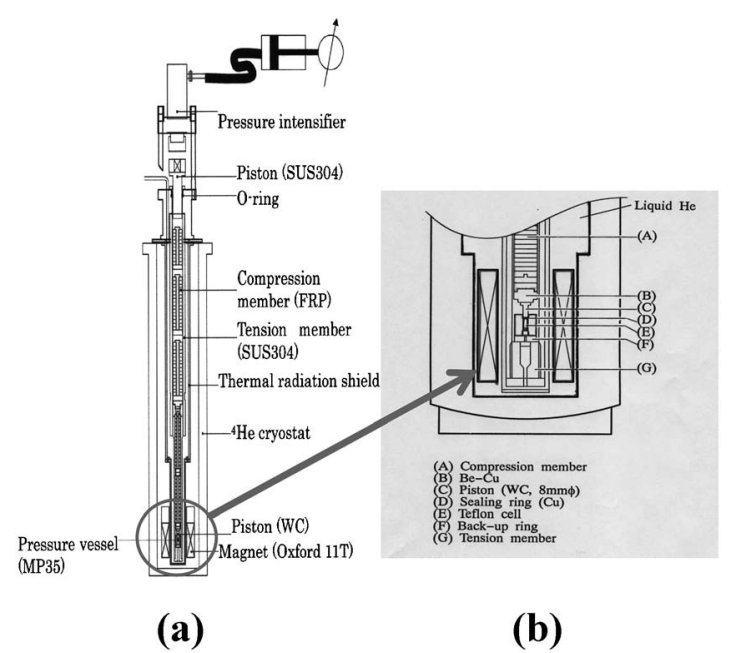

Fig. 1. Cross section of the present versatile high-pressure apparatus for the measurement at high magnetic field and low temperature (a) and the bottom part in the extended scale (b).

マグネットを加えたものである。細かい点を含めて いろいろと改良を重礼たが，詳細は原著論文[2,3] を見られたい。

\section{3. 強相関系物質における高圧力下の電子状態の研究}

圧力下の実験を計画するとき，一つの視点として 「その物質の物理量が高圧力下で大きな変化をする だろうか」と言う期待がある。圧力をかけてもびく ともしない物質は世の中に多い。他方, 圧力をかけ て常圧下では予想もできなかった新しい性質が出て くると我々は血沸き肉躍る経験をする。また，それ を通して研究に新しい切り口が見つかり, 当該分野 にブレイクスルーをもたらすことはよくあることで ある。前者は後者に比べて“押しがい”のない物質 と言われるときがある。しかし物理量を測定して小 さな変化であるけれどもそれが重要な場合もある。 例えば鉄の自発磁化の圧力効果などはその例であろ う。バンド計算等の理論的結果と直接比較できるの で, 1960 年ごろの測定值がいまだに用いられてい る $[4]$ 。ブリッジマンなどをはじめ, 圧力下の測定 を始めたころの十分な装置もないうちに， 50～60 年たった今でも使われるようなデータを出した先輩 たちの深い洞察と高い技術力を知るとき，その根底 に流れる学問の深さを痛感するのは筆者だけであろ うか。 
このようなことを考えるとき, 高圧力下の研究ス タイルに大きく分けて 2 つ行き方があることがわ かる。一つは, 高い圧力をめざしなおかつその時代 の最先端の典型的物質の物性を追うと言う行き方と, もう一つは, 地味ではあるが圧力は低いものの学問 的に重要な物理量を追うと言う行き方であろう。ど ちらを取るかはその人の学問観や立場などによるが, 実際はこの 2 つ間と言う人が大半ではなからうか。 筆者はカナダに留学したが，そこではどちらかと言 うと後者の立場の人が多かったような気がする。帰 国してからも九州にいたからではないが, 研究スタ イルはやや後者のそれとなってしまった。“押しが い”のある物質としては固体電子論的立場から出て くるものの一つに「極限的な電子状態」一いわゆる, “marginal electronic state”一にある物質と言うのが 一つの解ではなからうか。これらの物質の特徵は, 磁場, 温度や圧力などの広い意味の外力の作用を極 端に変化させた（極限環境）もとでそれらの電子状 態が大きく変化すると言うことが共通項として出て くる。以下では, そのような研究例を挙げていくこ とにする。

\subsection{Ce を含む重い電子系物質の電子状態の圧力誘} 起クロスオーバー

重い電子系物質とは, 伝導電子の有効質量が通常 金属のそれより 2 桁から 3 桁大きい物質群の総称で ある $[5]$ 。大变狭いバンドを形成し, 不安定な電子 状態を持つため, 圧力などの外部変数の作用で重い 電子状態は容易に壊れ, その結果として物理量が大 きな圧力変化をすることで知られている $[6,7]$ 。本 研究で開発された装置を使って, 例えば $\mathrm{CeInCu}_{2}$ [8]や $\mathrm{CePtSi}_{2}$ [9]等の 112 系, $\mathrm{CeRh}_{2} \mathrm{Si}_{2}$ [10]に代表 される 122 系などの物質で重い電子状態にある物質 を中心として高圧力下の電気抵抗, 熱膨張率, 磁気 抵抗及び磁歪等，また X 線回折を用いた諸測定を 行うことにより, これらの物質の高圧力下に抢ける 電子状態について系統的な実験を行ってきた。これ らの物質に共通する振る舞いは, “高圧力下で重い 電子状態が崩壊し, 混合原子価状態に移っていく” と言う電子状態のクロスオーバーが観測されること であった $[6,7]$ 。

例として典型的な重い電子系物質である $\mathrm{CeAl}_{3}$ (電子比熱係数 $\gamma \sim 1.5 \mathrm{~J} / \mathrm{mol} \cdot \mathrm{K}^{2}$ ) の電気抵抗の温 度変化 $\rho(T)$ を示した（Fig. 2, [11]）。1 気圧では 重い電子系物質の特徵である $35 \mathrm{~K}\left(=T_{\max }\right)$ 近傍に

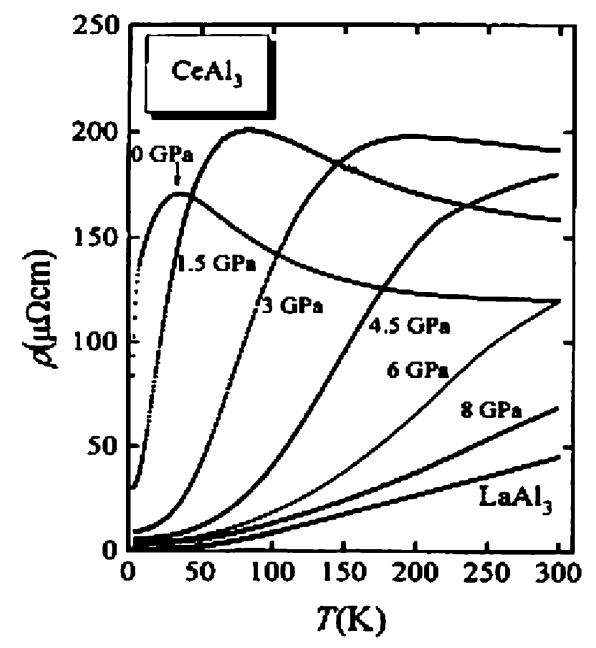

Fig. 2. Temperature dependent electrical resistivity $\rho(T)$ of the heavy fermion substance $\mathrm{CeAl}_{3}$ under high pressure. The $\rho(T)$ of $\mathrm{LaAl}_{3}$ is also shown for comparison.

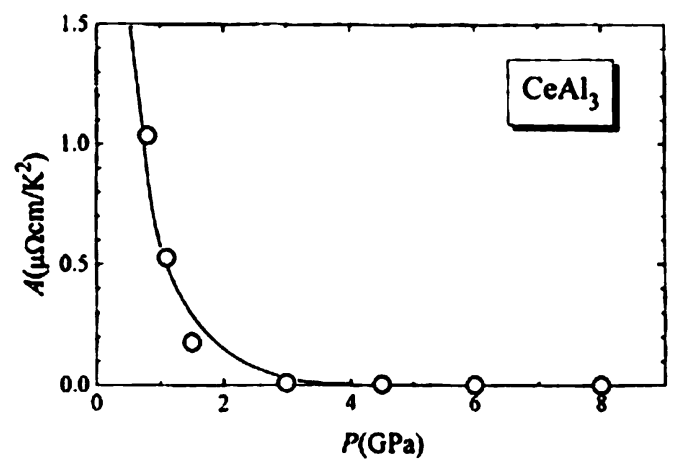

Fig. 3. The coefficient $A$ of $T^{2}$-term at low temperature as a function of pressure.

ピークを持つ構造を示す。それ以上の温度では電気 抵抗は近藤効果により $\log T$ 依存を示す。この物質 の $\rho(T)$ は低温で Fermi 液体特有の $T^{2}$ 依存を示し, その係数 $A$ は高圧力下で大きく減少する (Fig. 3)。 電子状態の評価をするため, この系の特性温度であ る近藤温度 $T_{\mathrm{K}}$ のグルナイゼンパラメーター $\Gamma$ を導 入し，その体積 (圧力) 変化を調べた。 $\Gamma$ は,

$$
\Gamma=-\frac{\partial \ln T_{\mathrm{K}}}{\partial \ln V}
$$

と定義される。 $T_{\mathrm{K}}$ は $A, T_{\max }$ と以下の関係にある。

$$
A \propto T_{\mathrm{K}}^{-2}, \quad T_{\max } \propto T_{\mathrm{K}}
$$


$\Gamma$ の值は Fig. 2 や 3 の結果と体積の圧力変化を使 って求められた $[11]$ 。その結果, 1 気圧では $\Gamma=97$ と大きな值であった（通常金属では $\Gamma$ は大体 $1 \sim 10$ 程度である）が圧力下で減少し，高圧力下ではいわ ゆる混合原子価物質と同程度の值（ $(\Gamma \sim 10 ）$ になる ことを明らかにした。この結果から有効質量も高圧 力下では大きく減少することになり, 重い電子状態 が圧力下で崩壊することがわかった。この問題は所 謂量子相転移々深く関連している。即ち, もともと $\mathrm{CeAl}_{3}$ は 1 気圧で量子臨界点直上にあり, marginal electronic state となっているが圧力をかけると臨界 点から離れ，通常金属と同じ電子状態になることを 示している。このような現象は他の重い電子系物質 $\mathrm{CeInCu}_{2}$ や $\mathrm{CeCu}_{6}$ 等にも同じようにみられている $[12]$ 。

\section{$3.2 f$ 電子系物質における圧力誘起超伝導}

前節の重い電子系物質に扔ける電子状態の圧力誘 起クロスオーバーは, 定性的には近藤温度のグルナ イゼン係数の圧力変化を用いて説明された。しかし， このような電子転移の研究をもっと進めて例えば, 磁気秩序がなくなってから新しく誘起される電子状 態として超伝導がクローズアップされ, 現在も盛ん に研究が抢こなわれている。詳しくは文献 6,7 を 見ていただきたい。ここでは, 我々が関与した $2 つ$ の物質について紹介する。

\subsection{1 $\mathrm{UGe}_{2}$}

興味ある例として $5 f$ 電子化合物 $\mathrm{UGe}_{2}$ を挙げる。 この物質は強磁性であり, 磁気転移点 $T_{\mathrm{M}}$ (以下で 出てくる超伝導転移点が $T_{\mathrm{c}}$ で表されるため, 混同

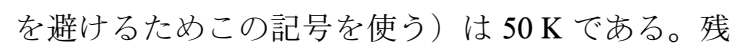
留抵抗比が 600 程度（あるいはそれ以上）と驚異的 な值を示す。単結晶試料の $\mathrm{b}$ 軸方向の熱膨張は温 度の関数として特異な振る舞いをする（Fig. 4, $[13]) 。 \mathrm{~b}$ 軸の長さは, 1 気圧では $T_{\mathrm{M}}$ 以下で膨張し， 典型的な磁気体積効果を示す。また $T_{\mathrm{M}}$ 以下で $\mathrm{b}$ 軸 は $25 \mathrm{~K}\left(=T^{*}\right)$ 近傍で小さな異常を示す。 $T_{\mathrm{M}}$ は 圧力をかけると大きく減少し, 大体 $1.8 \mathrm{GPa}$ ぐら

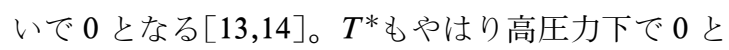
なる。ところが, 電気抵抗の $T^{2}$ 項の係数 $A$ は $1.1 \mathrm{GPa}$ 近傍で発散した（Fig. 5)。特性温度を $1 / \sqrt{A}$ と定義して圧力の関数としてプロットすると Fig. 5 の内装図のようになり, 特性温度が 0 となる のは $1.1 \mathrm{GPa}$ 近傍となる。上で述べた $T_{\mathrm{M}}=0$ とな

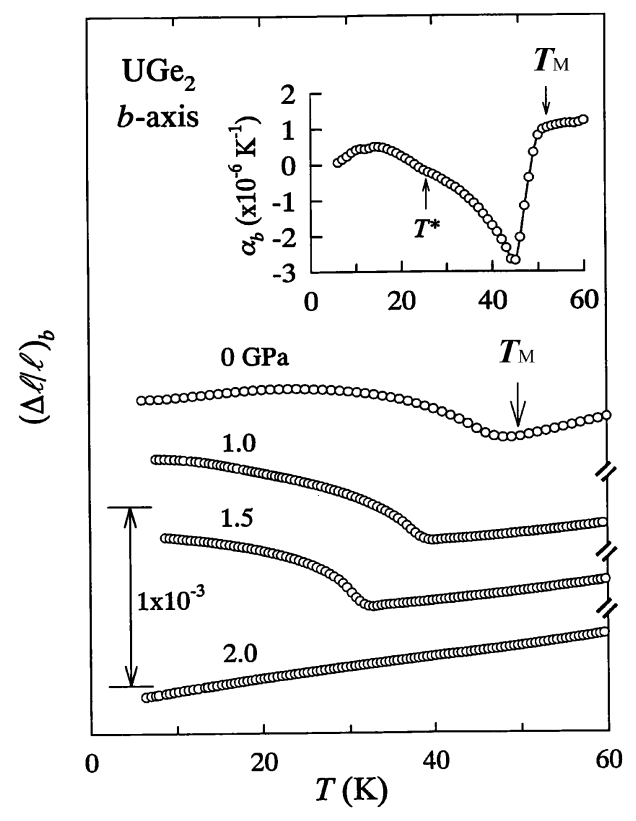

Fig. 4. Linear thermal expansion $\Delta l / l$ along b-axis of single crystalline $\mathrm{UGe}_{2}$ as a function of temperature at various pressure. The Curie temperature $T_{\mathrm{M}}$ at ambient pressure is shown by an arrow.

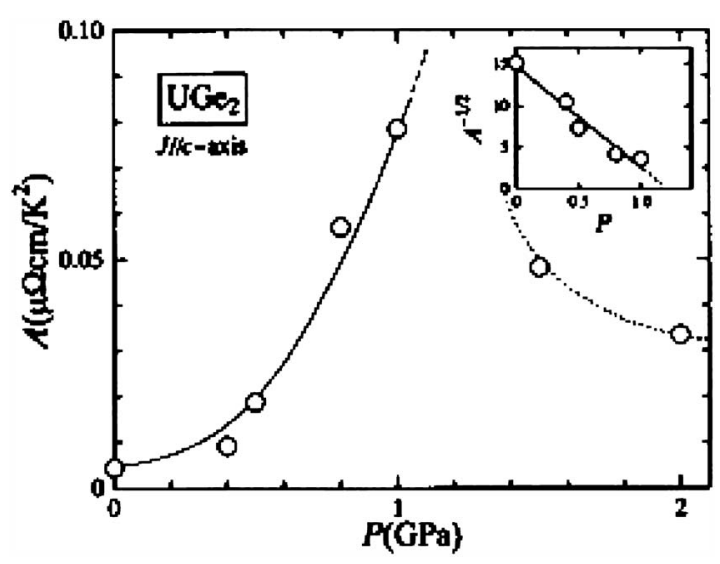

Fig. 5. The coefficient $A$ of the $T^{2}$ term of single crystalline $\mathrm{UGe}_{2}$ as a function of pressure. The solid and dashed curves are guides to the eye. The pressure dependence of $1 / \sqrt{A}$ is shown in the inset.

る圧力 $1.8 \mathrm{GPa}$ より低いことになる。この奇妙な 結果の解釈には大変悩んだが, 電気抵抗が小さな異 常を示す温度や上で述べた $T^{*}$ がやはりこの圧力で 0 となることを考えると, “1 GPa 近傍で何らかの 相転移がある”ことを示唆している $[15]$ 。結局, こ 


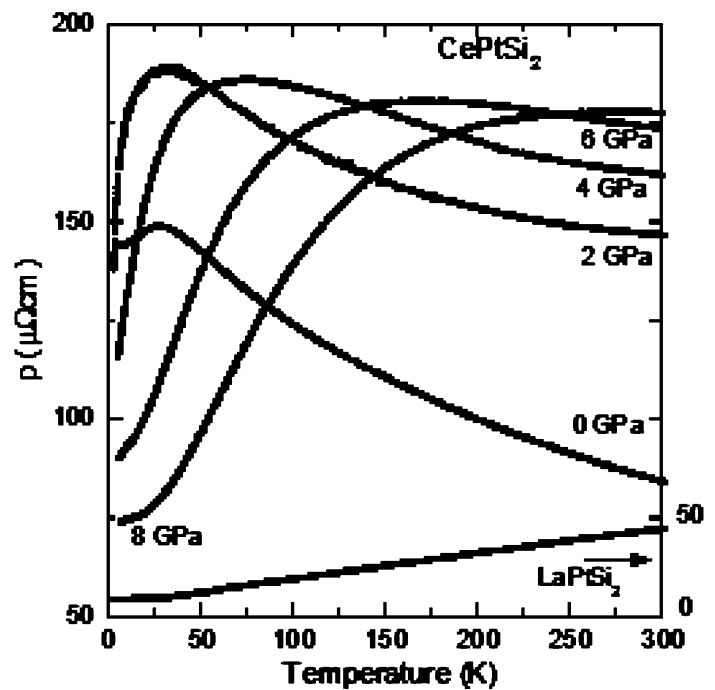

Fig. 6. The $\rho(T)$ of $\mathrm{CePtSi}_{2}$ at high pressure in the range $0<P<8 \mathrm{GPa}$.

の転移の原因を考えているところに Cambridge の Saxena 達がこの圧力付近での超伝導を $0.8 \mathrm{~K}$ で発 見した $[16]$ 。上で発見した奇妙な異常は，超伝導の 前駆現象だったのである。当該分野の競争が国際的 にいかに激しく行われていたかを示す典型的な例で あろう。

\subsection{2 $\mathrm{CePtSi}_{2}$}

上で述べたように，圧力誘起の磁気秩序消失や電 子状態のクロスオーバーがあった時，それ以上の圧 力で誘起される混合原子価や常磁性状態のほかにま れにではあるが超伝導が誘起される場合があること を述べた。次に $4 f$ 電子系の例として $\mathrm{CePtSi}{ }_{2}$ を見 てみよう。この物質は電子比熱係数が $0.6 \mathrm{~J} / \mathrm{mol} \cdot \mathrm{K}^{2}$ の重い電子系に属する。 $\mathrm{CePtSi}{ }_{2}$ の電気抵抗の高圧 力下に抢ける温度変化を測定すると, 前節の $\mathrm{CeAl}_{3}$ で見られたような重い電子系物質特有の $\rho(T)$ で山 を持つような振る舞いが 1 気圧では見られるが，圧 力を上げるにしたがって滑らかな曲線となり， $8 \mathrm{GPa}$ では混合原子価状態の物質によく似た $\rho(T)$ となる（Fig. 6）［9］。これは近藤温度が低い，重 い電子状態が崩壊し，近藤温度の高い混合原子価状 態へクロスオーバーしたことを示す。他方，高圧力 下の比熱の測定から反強磁性秩序は $1 \mathrm{GPa}$ 近傍で

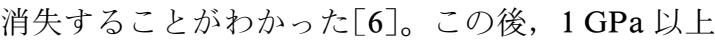
で $50 \mathrm{mK}$ までの電子状態は中野らによって詳細に
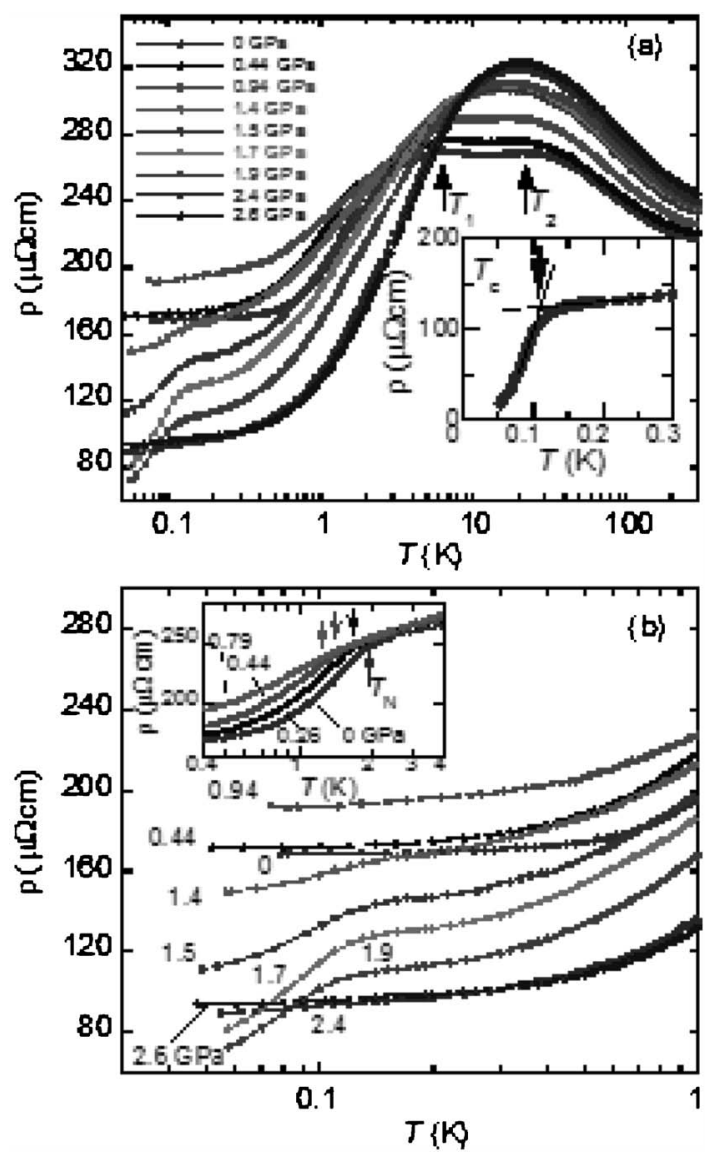

Fig. 7. (a) The $\rho(T)$ of $\mathrm{CePtSi}_{2}$ below $2.6 \mathrm{GPa}$ in the logarithmic scale. The two temperatures showing the peak in $\rho(T), T_{1}$ and $T_{2}$ are shown by arrows. The inset of (a) shows the details of $\rho(T)$ around superconducting transition temperature $T_{\mathrm{c}}$ at $1.7 \mathrm{GPa}$ measured with a low excitation current. (b) The $\rho(T)$ of $\mathrm{CePtSi}_{2}$ at high pressure below $1 \mathrm{~K}$. The Néel temperatures $T_{\mathrm{N}}$ are shown by arrows in the inset of (b).

調べられた（Fig. 7, [17]）。反強磁性転移温度が加 圧とともに下がり，消失する圧力近傍 $1.4 \mathrm{GPa}$ 以 上で Fig. 7b に見られるように超伝導が現れている。 いくつかの特性温度（抵抗がピークを持つ温度, $T_{1}, T_{2}, T_{\max }$ やネール温度 $T_{\mathrm{N}}$ ） や残留抵抗值，抵抗 のべき $n$ をプロットしてみると Fig. 8 のようにな る。これらの系特有の複雑な電子相の中で超伝導が 実現していることがわかる。興味深いのは Ce の価 数が変化する圧力 $\left(\mathrm{Fig} .8 \mathrm{~b}\right.$ の $\left.P_{\mathrm{v}}\right)$ 以上で超伝導が 出現していることである。価数転移と超伝導がどの ように関連しているのか興味ある問題であるが，そ の解決は今後の研究に委ねたい。 


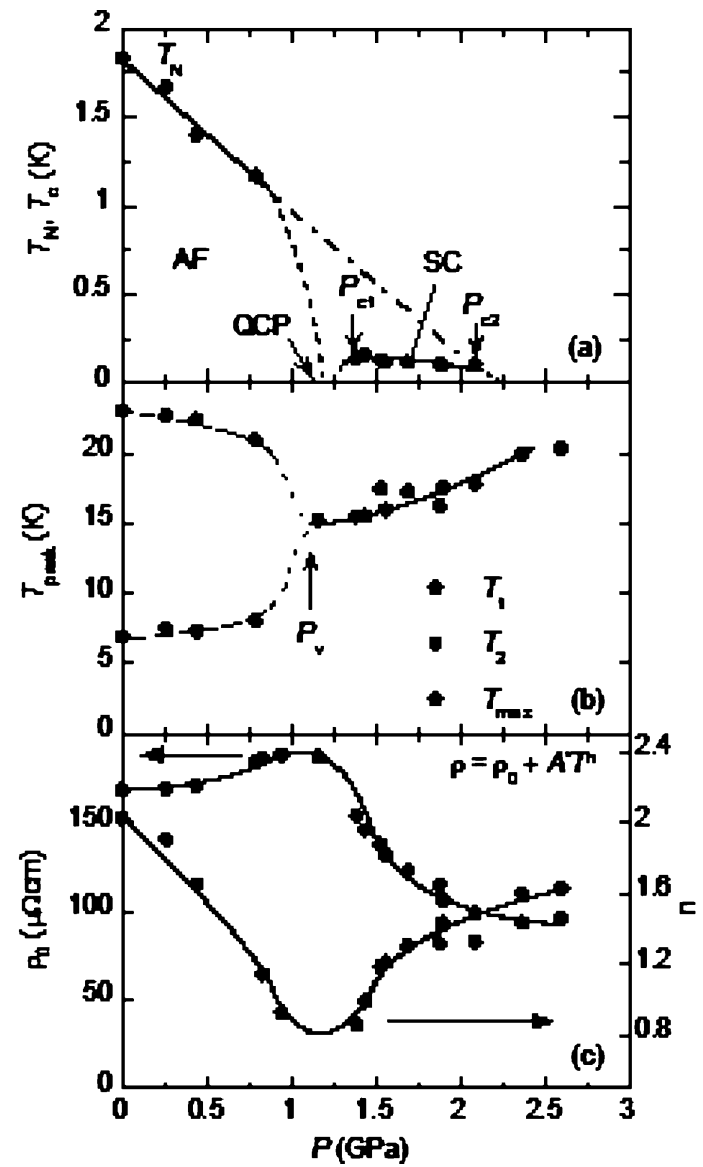

Fig. 8. (a) Phase diagram of $\mathrm{CePtSi}_{2}$ under high pressure. The dashed line is the expected pressure dependence of $T_{\mathrm{N}}$. The dash-dotted line is a linear extrapolation. (b) $T_{1}, T_{2}$ and $T_{\max }$ as a function of pressure. (c) residual resistivity $\rho_{0}$ and the power $n$ in the temperature dependence of $\rho$. The lines are guide to the eye.

\section{4. ナノスケール磁性体における輸送現象の圧力効果}

人工格子やナノグラニュラー系物質は磁性（スピ ン構造）と輸送現象とが密接に結びついた系である。 この特異な電子構造に着目し, 高圧力下の磁気抵抗 を測定することにより，スピンに依存する電気抵抗， 即ち $\mathrm{Fe} / \mathrm{Cr}$ の巨大磁気抵抗 (Giant Magnetoresistance: GMR) や Co-Al-O のトンネル型磁気抵抗 (Tunnel Magnetoresistance: TMR) が圧力下でどの ように振る舞うかを究明した。以下で, これらの成 果を2つに分けて紹介する。

\section{1 高圧力下における金属人工格子の GMR}

$\mathrm{Fe} / \mathrm{Cr}$ や $\mathrm{Co} / \mathrm{Cu}$ 人工格子は強磁性の $\mathrm{Fe}$ 層と $\mathrm{Co}$ 層とが反平行に配列された層状構造を持つGMR を 示す典型的物質である $[18]$ 。これらの物質では反平 行スピン配列が外部磁場に強く依存し，それによる 電子散乱が大きく変化するため GMR が起きる。ま た，これらの物質の GMRの大きさは常磁性層の膜 厚で振動し， $1^{\text {st }}$ peak, $2^{\text {nd }}$ peak などと呼ばれている。 ほとんどの人工格子の GMR は圧力下では減少する [19］。ところが， $2^{\text {nd }}$ peak $の \mathrm{Fe} / \mathrm{Cr}$ の GMR を高圧 力下で測定すると, $2 \mathrm{GPa}$ の加圧で常圧の 2 倍近く にも GMR は増大することがわかった $[20]$ 。 $1^{\text {st }}$ peak に属する試料, $\left[\mathrm{Fe}(20 \AA) / \mathrm{Cr}\left(t_{\mathrm{Cr}}=10 \AA\right)\right]_{20}$, $(\mathrm{Fe} / \mathrm{Cr}(10)$ と略）と 2nd peak に属する試料, $[\mathrm{Fe}$ $\left.(20 \AA) / \mathrm{Cr}\left(t_{\mathrm{Cr}}=30 \AA\right)\right]_{20}$ と（ $\mathrm{Fe} / \mathrm{Cr}(30)$ と略 $)$ の 磁気抵抗（MR）効果の測定例を Fig. 9 の (a), (b) に示す。(a)では $2.5 \mathrm{GPa}$ の圧力をかけても MR の 值はそれほど変化しない。わずかに下がるだけであ る。他方，（b)では常圧の MR curve と比べて $2 \mathrm{GPa}$ の加圧で MR は 2 倍以上に増加している。 末永たちはその原因をスピン間のカップリングのク ロスオーバーによるものと結論した $[20]$ 。この一連 の研究において, この結果に到達するのに我々は実 に 15 年の歳月を費やした。成果が常に急がれる昨 今の状況では考えられないような大変悠長な仕事に なってしまった $[1]$ 。

\section{2 ナノグラニュラー物質における TMR の圧カ 効果}

Co-Al-O は非晶質アルミナの中に Co の微粒子 が散布された構造を持ち，トンネル効果により特異 な電気伝導をする。また，Co 微粒子のスピンの向 きがトンネル伝導に影響を与えるため大きな TMR を示す。加治らはこの系に圧力をかけ，TMR や輸 送現象を詳細に調べた $[21]$ 。これらの結果を解析す ることにより，圧力は微粒子のサイズよりも粒子間 距離に強く影響を及ぼすこと，また Fig. 10 に示す ように $4.2 \mathrm{~K}$ でトンネル効果を増大させ，TMRの 大きさを増加させることを明らかにした。更に圧力 を上げるとパーコレイションの効果により，トンネ ル効果はなくなり，図に示すように TMR は急激に 小さくなった。これらの結果は“量子効果であるト ンネル伝導に圧力をかける試み”で学会から注目さ れた。更に, TMR の圧力効果の測定は昇と桜庭ら により, ハーフメタルホイスラー合金 $\mathrm{Co}_{2} \mathrm{MnSi}$ を 


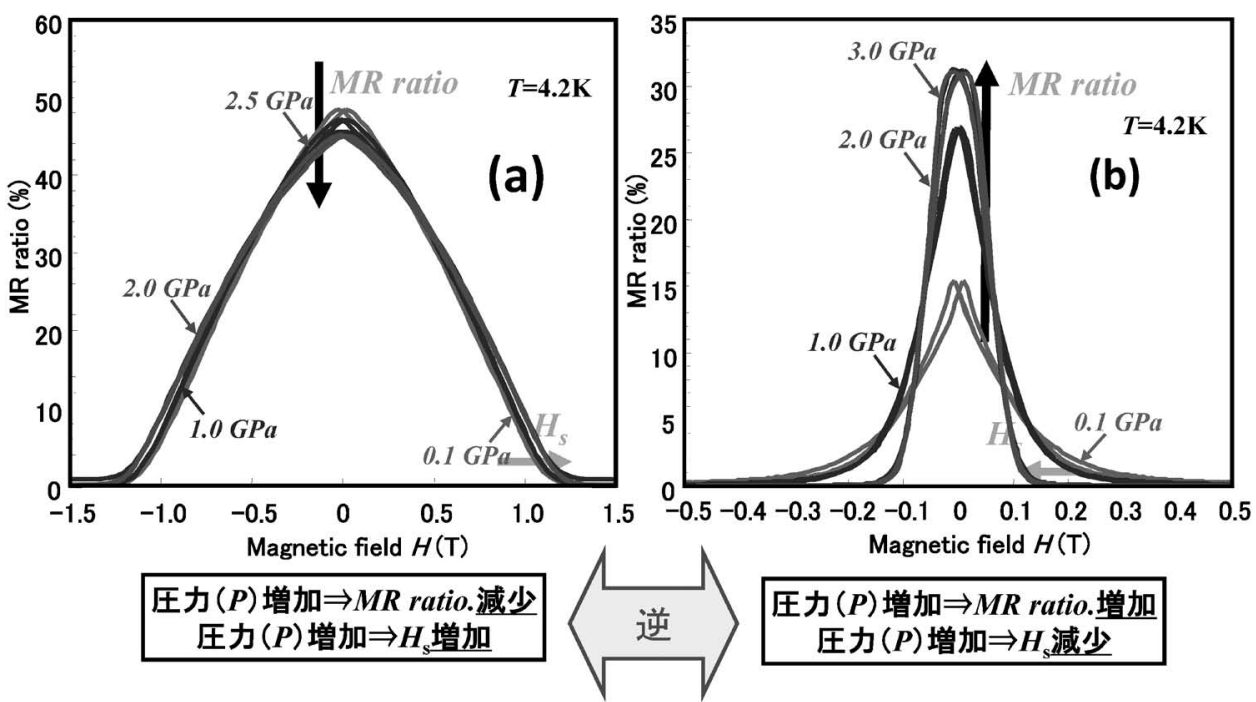

Fig. 9. Magnetoresistance (MR) curves at $4.2 \mathrm{~K}$ for two magnetic multilayers at high pressure, (a) $\mathrm{Fe} / \mathrm{Cr}(10)$ and (b) $\mathrm{Fe} /$ $\mathrm{Cr}(30)$. The arrows indicate increasing pressure.

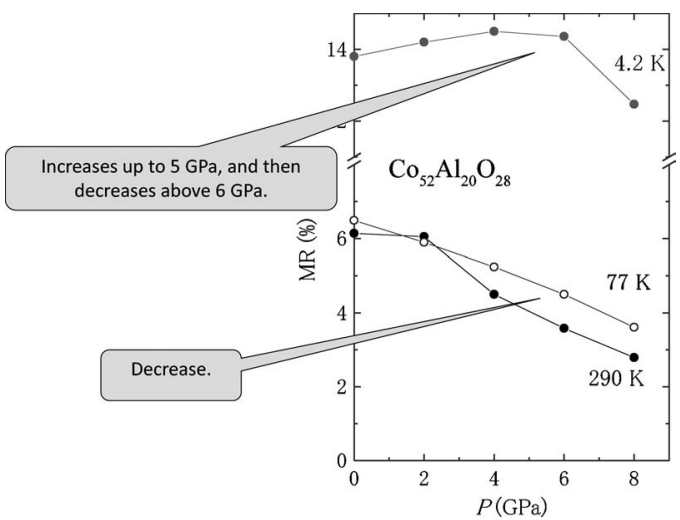

Fig. 10. MR ratio of granular oxide $\mathrm{Co}-\mathrm{Al}-\mathrm{O}$ at various temperatures as a function of pressure.

ベースとしたナノ構造物質にも応用され，興味ある 結果を得た $[22]$ 。

\section{5. コンプトン効果を用いた金属リチウムの高圧力} 下における電子状態

これまで 3,4 で述べてきた測定は電子状態を電 気抵抗や熱膨張で “間接的に” 久る方法であった。 高圧力下に抢ける伝導電子の状態を “直接的に” 知 る方法としてコンプトン散乱の測定を提唱した。こ の測定により電子の運動量分布に及ぼす圧力効果を
知ることができる。これは技術的に難しいと当時は 思われていたので, 装置や光学系の開発など多くの 研究者に協力してもらい研究を進めた。東北大学の 金研の伊藤先生と協力して, 通常の $\gamma$ 線源を用いて 予備実験を行い, 最終的には高エネルギー物理学研 究所で下村さんたちと協力して，放射光を使って Fig. 11 に示すような金属 $\mathrm{Li}$ の高圧力下のコンプト ンプロファイルの観測に成功し，伝導電子のフェル ミ面が高圧力下で広がっていることが明らかとなり [23]，その結果が自由電子模型で説明できることを 示した。この実験により高圧力下のコンプトン散乱 実験が可能であることを示すことができた。その後, ヨーロッパなどで同様な実験がなされた。

\section{6. おわりに…高圧力下の物性研究体制についての 一考察}

私が熊本大学の助教授となった頃 (1987, 40 歳 11 か月), 上でも述べたように, 教養部の廃止が多 くの大学で進むと同時に学部や研究センターの改 組・新設など我が国の大学は生き残りをかけて新し い体制の構築に乗り出していた。九州内の大学でも 既存の学部が新しく聞いたこともないような名前の 学部として生まれ変わって行ったのを目の当たりに した。物性研究も当然ながらこの荒波を受けること となり, 当時の物性委員会では「物性研究拠点整備 

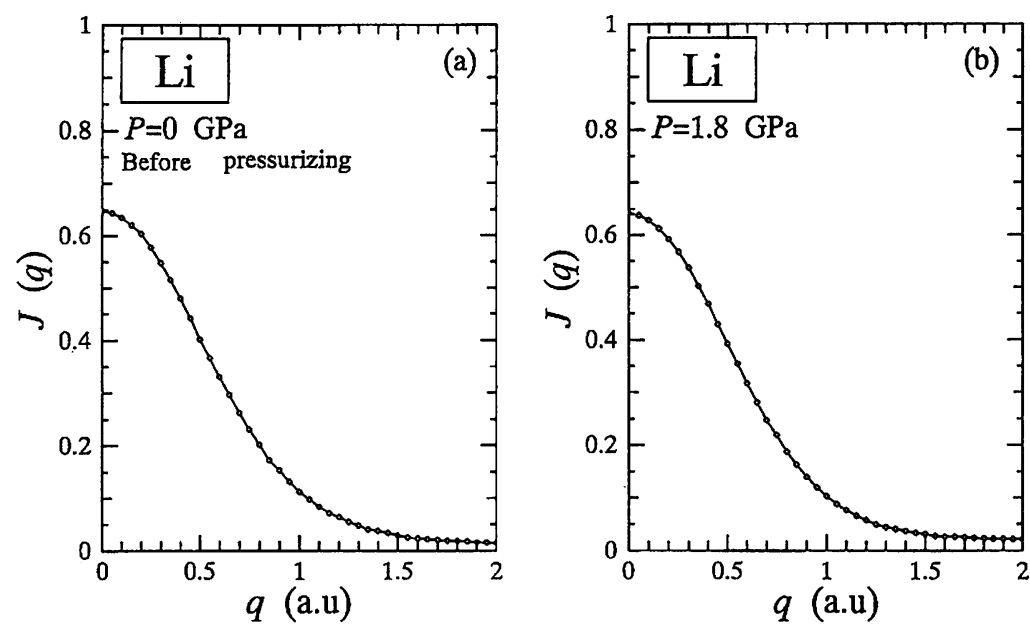

Fig. 11. Compton profile $J(q)$ of $\mathrm{Li} \mathrm{(a)} \mathrm{at} \mathrm{ambient} \mathrm{pressure} \mathrm{and} \mathrm{(b)} \mathrm{at} 1.8 \mathrm{GPa}$.

計画」(平成 12 年学術会議より対外報告が出た) と 言う案を作り，全国的な物性研究者のネットワーク を作ろうとしていた。当時所属していた熊本大学で も教養部が廃止され，新しくどのような研究教育体 制を作るべきか議論されていた。極限物性関係では 衝撃エネルギー実験所や理学部極低温室が学内にあ ったが，これらを統合して省令施設に格上げしよう という計画があり，わたくしもそれに微力ながら加 わることとなった。この案は関係者の努力もあり， 平成 11 年度より「衝撃・極限環境研究センター」 として定員増を伴って発足することとなった。各大 学で拠点計画を基にその大学独自の物性物理の研究 体制が築かれていったが, 平成 16 年以降の大学の 独立行政法人化の影響で現在, また新しい物性研究 の体制が議論されていると聞く。物性研究は素粒 子・原子核・宇宙分野の巨大科学々違って, 装置も 小規模である。そのような視点で全国の高圧科学を 見ると各地方に特色ある装置が開発されていること に気付く。今後はそのような装置を開放し, ネット ワークを築けば当該分野はより発展するものと考え る。

\section{謝 辞}

本論文で紹介した一連の研究は多くの方々のご援 助によるものです。低温高圧の研究の手ほどきは故 三井惟靖教授（北海道大学）及び毛利信男教授（北 海道大学, 東京大学) から受けました。熊本大学在 職中は上床美也氏（現, 東京大学), 加賀山朋子氏
(現，大阪大学）に，また，九州大学では大橋政司 氏 (現, 金沢大学), 中野智仁氏 (現, 新潟大学) 及び本多史憲氏（現，東北大学）の支援にあずかり ました。この受賞の機会に厚く御礼申し上げます。 また, 研究室の多くの学生, 同僚, 及び内外の共同 研究者の打世話になりました。ここに心から謝意を 表します。最後になりましたが，本学会賞の受賞は 身に余る光栄であります。関係者の方々に心より感 謝いたします。

\section{参考文献}

[1] 巨海玄道 : Magnetics Jpn., 5, 405 (2010).

[2] 巨海玄道, 加賀山朋子 : 高圧力の科学と技術,

4, 238 (1995).

[3] F. Honda, S. Kaji, M. Ohashi, G. Oomi, T. Eto, T. Kagayama: J. Phys. Condens. Matter, 14, 11501 (2002).

[4] J.S. Kouvel, R.H. Wilson: J. Appl. Phys., 32, 435 (1961).

[5] 上田和夫，大貫惊睦：重い電子系の物理(裳華 房, 1998).

[6] 最近の高圧力下の振る舞いに関する総合報告と して以下の文献がある。

Y. Uwatoko, I. Umehara, M. Ohashi, T. Nakano, G. Oomi: Handbook on the Physics and Chemistry of Rare Earths, 42, Chap. 252 (2012).

[7] Novel Pressure-induced Phenomena in Condensed Matter Systems, J. Phys. Soc. Jpn., Suppl. A, 76 (2007) (Proc.Intern,Workshop on Recent Progress in the High Pressure Research, ed.by T. Kagayama, M. Ohashi, Y. Uwatoko). 
[8] T. Kagayama, G. Oomi, H. Takahashi, N. Mori, Y. Ōnuki, T. Komatsubara: Phys. Rev. B, 44, 7690 (1991).

[9] G. Oomi, T. Kagayama, Y. Uwatoko, H. Takahashi, N. Môri: J. Alloys \& Compd., 207 \& 208, 278 (1994).

[10] M. Ohashi, G. Oomi, S. Koiwai, M. Hedo, Y. Uwatoko: Phys. Rev. B, 68, 144428 (2003).

[11] T. Kagayama, G. Oomi: J. Phys. Soc. Jpn., 65, Suppl. B, 42 (1996).

[12] T. Kagayama, G. Oomi: "Transport and Thermal Properties of f-electron Systems" eds. G. Oomi, H. Fujii, T. Fujita (Plenum, New York), 155 (1983).

[13］巨海玄道, 本多史憲, 加賀山朋子, 大貫嵉 睦：日本物理学会誌 (最近の研究から), 56, 517 (2001).

[14] K. Nishimura, G. Oomi, S.W. Yun, Y. Ōnuki: J. Alloys \& Compd., 213 \& 214, 383 (1994).

[15] G. Oomi, T. Kagayama, Y. Ōnuki: J. Alloys and Compd., 271-273, 482 (1998).

[16] S.S. Saxena, P. Agarwal, K. Ahilan, F.M. Grosche, R.K.W. Haselwimmer, M.J. Steiner, E. Pugh, I.R. Walker, S.R. Julian, P. Monthoux, G.G. Lonzarich, A. Huxley, I. Sheikin, D. Braithwaite, J.
Flouquet: Nature, 406, 587 (2000).

[17] T. Nakano, M. Ohashi, G. Oomi, K. Matsubayashi, Y. Uwatoko: Phys. Rev. B, 79, 172507 (2009).

[18] M.N. Baibich, J.M. Broto, A. Fert, F. Nguyen Van Dau, F. Petroff, P. Etienne, O. Creuzet, A. Friederich, J. Chazelas: Phys. Rev. Lett., 61, 2472 (1988).

[19] G. Oomi, T. Sakai, Y. Uwatoko, K. Takanashi, H. Fujimori: Physica B, 239, 19 (1997).

[20] K. Suenaga, S. Higashihara, M. Ohashi, G. Oomi, M. Hedo, Y. Uwatoko, K. Saito, S. Mitani, K. Takanashi: Phys. Rev, Lett., 98, 207202 (2007). [21] S. Kaji, G. Oomi, M. Hedo, Y. Uwatoko, S. Mitani, K. Takanashi, S. Takahashi, S. Maekawa: J. Phys. Soc. Jpn., 74, 2783 (2005).

[22] M. Nobori, T. Nakano, J. Hasegawa, G. Oomi, Y. Sakuraba, K. Takanashi, Y. Miura, Y. Ohdaira, Y. Ando: Phys. Rev. B, 83, 104410 (2011).

[23] G. Oomi, F. Honda, T. Kagayama, F. Itoh, H. Sakurai, H. Kawata, O. Shimomura: Jpn. J. Appl. Phys., 38, Suppl. 38-1 (1999) 508.

[2013 年 2 月 15 日受付, 2013 年 4 月 17 日受理 $]$ (C) 2013 日本高圧力学会 